\begin{tabular}{r|l|l|l}
$\begin{array}{c}\text { Case Reports in } \\
\text { Gastroenterology }\end{array}$ & $\begin{array}{l}\text { Case Rep Gastroenterol 2010;4:421-428 } \\
\text { DOl: 10.1159/000320871 }\end{array}$ & $\begin{array}{l}\text { Published online: } \\
\text { October 5, 2010 }\end{array}$ & $\begin{array}{l}\text { O 2010 S. Karger AG, Basel } \\
\text { ISSN 1662-0631 } \\
\text { www.karger.com/crg }\end{array}$ \\
\hline
\end{tabular}

This is an Open Access article licensed under the terms of the Creative Commons AttributionNonCommercial-NoDerivs 3.0 License (www.karger.com/OA-license), applicable to the online version of the article only. Distribution for non-commercial purposes only.

\title{
Metastatic Renal Cell Cancer and a Gastric Mass: An Unusual Finding
}

\author{
Viplove Senadhi ${ }^{a}$ Niraj Jani ${ }^{b}$ Rodrigo Erlich ${ }^{c}$ \\ aJohns Hopkins University/Sinai Hospital Program in Internal Medicine, \\ Department of Internal Medicine, Sinai Hospital, Baltimore, Md., 'bl Oncology/ \\ Endoscopic Ultrasound Director, Johns Hopkins University/Sinai Hospital \\ Program, Division of Gastroenterology, Sinai Hospital, Baltimore, Md., and \\ 'Medical Director Foxchase Geisinger Medical Oncology, Division of Hematology \\ and Oncology, Danville, Pa., USA
}

\section{Key Words}

Gastric cancer $\cdot$ Renal cancer

\begin{abstract}
Renal cell cancer (RCC) accounts for approximately $3 \%$ of all adult malignancies. RCC has a metastasis rate of approximately $25 \%$, which is most commonly to the lungs ( $>50 \%$ ). On the contrary, RCC metastasis to the gastrointestinal tract (excluding the liver) is very uncommon and ranges from 0.2 to $0.7 \%$. Thus, a gastric cancer in a patient with known metastatic RCC would most likely be secondary to metastasis. We present the first reported case of a metastatic RCC coexisting with a new-onset primary gastric cancer and a review of management using guidelines from metastatic RCC to the stomach. An 82-year-old African American male with papillary RCC status post left nephrectomy with recurrence of liver metastasis presented with failure to thrive shortly after his third cycle of chemotherapy despite stable disease by imaging studies. He had received 7 chemotherapy cycles of Gemzar, Nexavar, and Avastin prior to admission. He subsequently had a drop in his hemoglobin and was found to have hemoccult positive stool in the setting of recent Avastin. Endoscopic evaluation showed a $3 \mathrm{~cm}$ ulcerated mass in the cardia which was biopsied. The biopsy showed invasive and poorly differentiated gastric adenocarcinoma unrelated to his RCC. The patient subsequently underwent partial gastrectomy with loop gastrojejunostomy for resection of his stage 1 primary gastric adenocarcioma. The surgery also facilitated future chemotherapy (Avastin), which could not be given prior to surgery due to its side effect of bleeding. The patient did not receive adjuvant chemoradiation for his gastric cancer due to his comorbidities at the time and was doing well at a one month follow-up. Metastatic RCC and primary gastric cancer can coexist, especially when there is an overlap of risk factors such as smoking or nitrosamines. The management of a gastric cancer in the setting of metastatic RCC is similar to the management of solitary primary gastric carcinoma.
\end{abstract}




\begin{tabular}{r|l|l|l}
$\begin{array}{r}\text { Case Reports in } \\
\text { Gastruanteriology }\end{array}$ & $\begin{array}{l}\text { Case Rep Gastroenterol 2010;4:421-428 } \\
\text { DOI: 10.1159/000320871 }\end{array}$ & $\begin{array}{l}\text { Published online: } \\
\text { October 5, 2010 }\end{array}$ & $\begin{array}{l}\text { O 2010 S. Karger AG, Basel } \\
\text { ISSN 1662-0631 } \\
\text { www.karger.com/crg }\end{array}$ \\
\hline
\end{tabular}

Treatment of the primary gastric cancer can facilitate future chemotherapy such as Avastin, which has been recently approved for the treatment of metastatic RCC.

\section{Introduction}

Renal cell cancer (RCC) is the most common type of renal tumor and has the highest incidence in the sixth decade and in men $(2 \times)$ [1]. Several risk factors predispose to RCC including tobacco smoking, obesity, asbestos, lead phosphate, nitrosamines, and genetic syndromes such as von Hippel-Lindau syndrome [1]. On the other hand, gastric carcinomas comprise less than $1 \%$ of all adult malignancies in the United States, with a higher incidence in Japan and Korea [2]. Risk factors for gastric cancer can be divided into genetic factors and modifiable risk factors. Genetic factors include pernicious anemia, type A blood (weak association), family history of cancer, Li-Fraumeni syndrome, and hereditary nonpolyposis coli [2]. Modifiable risk factors include tobacco smoking, $H$. pylori infection, radiation exposure, and dietary factors [2]. Dietary factors include high salt, low vitamin $\mathrm{A} / \mathrm{C}$ intake (low amounts of fruits/vegetables) as well as high nitrate intake (salted, pickled, chemically preserved foods). Smoking and nitrosamines are the only common risk factors in both RCC and gastric cell cancer. Our patient had a remote smoking history as well as asbestos exposure, which were probably the risk factors for his RCC.

To our knowledge, this is the first report describing a patient with metastatic papillary RCC to the liver and a primary, localized gastric adenocarcinoma. Interestingly enough, the patient presented with failure to thrive in the setting of chemotherapy and multifactorial anemia, which was primarily due to his gastric carcinoma.

\section{Case Report}

An 82-year-old African American male was admitted to our hospital with failure to thrive as defined by ECOG performance score 3 with specific complaints of generalized weakness and poor oral intake. He had undergone a left radical nephrectomy in 2004 for a grade 3 tumor approximately $4 \mathrm{~cm}$ in size invading the renal vein and perinephric adipose tissue. He did not receive any adjuvant chemotherapy or immunotherapy at the time and was followed up by his urologist. He had no evidence of recurrence until November 2008 when he was found to have liver metastasis with an $11 \mathrm{~mm}$ lesion and a $2.8 \mathrm{~cm}$ renal mass. A liver biopsy (fig. 1) showed metastatic papillary RCC and the patient was initiated on chemotherapy with Gemzar, Nexavar, and Avastin (7 cycles) prior to this hospital admission. The patient's metastatic disease looked stable by CT scan. The patient was initially thought to have failure to thrive due to catheter-related infection and had an associated leukocytosis of 19,000 cells/l upon admission.

The patient had no evidence of infection, but subsequently his Hct dropped and he was found to have a positive hemoccult in the setting of multifactorial anemia, on Procrit. Gastroenterology evaluation was warranted since the patient was on Avastin and the proven incidence of bleeding in Avastin is approximately 7-9\%. Additionally, the patient had no prior history of gastrointestinal (GI) bleeding. Although Avastin has been classically associated with nose bleeds and serious hemoptysis in patients with lung cancer, workup was initiated for future consideration of chemotherapy. The known side effects of Avastin in the GI tract include GI perforation/GI fistulas and there are reports of Avastin causing gastric/duodenal ulcers which have sometimes led to life-threatening or fatal bleeding [3]. There are also reports of minor GI bleeds that have heralded GI perforation [3]. This is especially important considering Avastin decreases angiogenesis and is associated with decreased wound healing, which is important in ulcer resolution. 


\begin{tabular}{r|l|l|l} 
Case Reports in & $\begin{array}{l}\text { Case Rep Gastroenterol 2010;4:421-428 } \\
\text { DOl: 10.1159/000320871 }\end{array}$ & $\begin{array}{l}\text { Published online: } \\
\text { October 5, 2010 }\end{array}$ & $\begin{array}{l}\odot \text { 2010 S. Karger AG, Basel } \\
\text { ISSN 1662-0631 } \\
\text { www.karger.com/crg }\end{array}$ \\
\hline
\end{tabular}

The patient had an EGD which showed a $3 \mathrm{~cm}$ ulcerated mass in the cardia (fig. 2 , fig. 3 ) which bled on contact and was subsequently biopsied (ig. 4). The biopsy showed invasive and poorly differentiated gastric adenocarcinoma (fig. 5, fig. 6). H. pylori was negative, which was expected due to the location being in the cardia. There has been an increase in gastric cancer in the cardia that has paralleled esophageal adenocarcinoma related to Barret's transformation and the increasing incidence of obesity in America [4]. Gastric cancers in the cardia are almost universally $H$. pylori-negative and there are studies in Europe that have shown a decreased incidence of esophageal carcinoma as well as gastric cancer in the cardia in patients with H. pylori [4]. Lastly, in the United States, the predominant location of gastric cancer is now in the cardia with $31 \%$, which is higher than the antrum with $26 \%$ [2].

The patient subsequently underwent a partial gastrectomy with loop gastrojejunostomy for resection of his stage 1 primary gastric adenocarcioma. He tolerated the procedure without complications and had a relatively short postoperative course to recovery. However, he did not receive adjuvant chemoradiation for his gastric cancer due to his comorbidities at the time. He did well after his discharge at a one month follow-up.

\section{Discussion}

RCC is known for its propensity to metastasize via both hematogenous mechanisms as well as (less commonly) lymphatics [5]. Ritchie and deKernion [5] reported that RCC presents with metastatic disease in $23 \%$ of cases and that metastasis occurs within 5 years of nephrectomy in $25 \%$ of cases, which occurred to the liver in our patient. The liver is a common site of metastasis for RCC due to the common inferior vena cava drainage of the renal vein and the hepatic vein. This is the only case, to our knowledge, of a patient with a papillary RCC with metastasis to the liver who also had a primary gastric adenocarcinoma. This discussion will cover the literature regarding gastric metastasis from RCC and subsequently the local management of primary gastric carcinoma.

Our patient presented with failure to thrive in the setting of metastatic RCC, which in turn led to an earlier diagnosis of primary gastric carcinoma. It is pivotal to diagnose gastric cancers prior to spreading, as the cancer is very amenable to surgery and possibly endoscopy if in the early stages of the disease. The usual presentation of gastric cancer is with early satiety, nausea, vomiting, weight loss, epigastric pain, or iron deficiency anemia in the case of ulceration. The presentation depends on the type of gastric cancer. The intestinal type of gastric cancer is more likely to present with the aforementioned symptoms as it is the result of a chronic inflammatory process. On the other hand, the diffuse type of gastric carcinoma is more prevalent in women and in individuals under the age of 50. Note that in a patient with a prior history of RCC, there are case studies illustrating that surveillance EGD can be performed in the setting of undiagnosed upper GI hemorrhage, as it may herald the recurrence of RCC [6].

On the other hand, in RCC metastatic to the stomach, metastasis was the presenting sign of the cancer in most cases or occurred during follow-up after nephrectomy with a mean of 6.6 years, which is later than any other metastasis site [7]. Presenting symptoms were mainly upper or lower GI bleeding and rarely anemia [5]. For patients with a solitary metastasis and with appropriate ECOG scores, gastrectomy is performed as a complementary treatment [8]. For patients with multiple or inoperable metastases, treatment consisted of either endoscopic resection, embolization of the metastasis, or immunotherapy [8]. The benefit of surgery in terms of survival could not be demonstrated due to the short follow-up of 8.6 months [9]. 


\begin{tabular}{r|l|l|l}
$\begin{array}{r}\text { Case Reports in } \\
\text { Gastruenterology }\end{array}$ & $\begin{array}{l}\text { Case Rep Gastroenterol 2010;4:421-428 } \\
\text { DOI: 10.1159/000320871 }\end{array}$ & $\begin{array}{l}\text { Published online: } \\
\text { October 5, 2010 }\end{array}$ & $\begin{array}{l}\text { O 2010 S. Karger AG, Basel } \\
\text { ISSN 1662-0631 } \\
\text { www.karger.com/crg }\end{array}$ \\
\hline
\end{tabular}

Surgical resection of the metastasis has been the preferred treatment in the case of a solitary metastasis and absence of contraindication related to the general state [8]. In other cases, endoscopic resection or embolization of the metastasis have been proposed, with or without systemic immunotherapy. There are numerous cases that confirm the potential of RCC for late and solitary metastasis with circumscribed local invasiveness, suggesting that endoscopic resection may be feasible [10]. Although recently, endoscopic mucosal resections have shown equivocal 5 -year survival to surgery for early gastric cancer with differentiated tumors that are slightly raised and less than $2 \mathrm{~cm}$ in diameter, or in differentiated tumors that are ulcerated and less than $1 \mathrm{~cm}$ in diameter [2], the role of targeted anti-tumor treatments, such as anti-angiogenic drugs, has not been evaluated [9].

A review of the literature shows that the management of a solitary gastric cancer, even in the setting of RCC with metastasis to unadjacent organs, is ideally surgical if the tumor is greater than $2 \mathrm{~cm}$ [8]. In our patient, the gastric cancer was $3 \mathrm{~cm}$ in size without nodal involvement, and thus not a candidate for endoscopic mucosal resection. The type of surgery performed depends on the extent and location of the tumor; therefore, preoperative evaluation is critical. Initial diagnosis may be established by endoscopy with biopsy. Endoscopic ultrasound should follow. Endoscopic ultrasound has a sensitivity of $85 \%$ in assessing the depth of tumor invasion and detecting nodal involvement prior to surgery [2]. Laparoscopic staging prior to surgical resection is also advocated and has impacted preoperative treatment decisions [2]. Lastly, as advocated by previous studies mentioned above, in a patient with a history of RCC who presents with failure to thrive and anemia, GI metastasis versus a primary tumor in the GI tract should be considered if risk factors overlap, especially when there is a history of smoking.

In conclusion, metastatic RCC and primary gastric cancer can coexist, especially when there is an overlap of risk factors such as smoking or nitrosamines. The management of a gastric cancer in the setting of metastatic RCC is similar to the management of solitary primary gastric carcinoma. Treatment of the primary gastric cancer can facilitate future chemotherapy such as Avastin, which has been recently approved for the treatment of metastatic RCC. 


\begin{tabular}{l|l|l|l}
$\begin{array}{r}\text { Case Reports in } \\
\text { Gastroenterology }\end{array}$ & $\begin{array}{l}\text { Case Rep Gastroenterol 2010;4:421-428 } \\
\text { DOl: 10.1159/000320871 }\end{array}$ & $\begin{array}{l}\text { Published online: } \\
\text { October 5, 2010 }\end{array}$ & $\begin{array}{l}\text { O 2010 S. Karger AG, Basel } \\
\text { ISSN 1662--0631 } \\
\text { www.karger.com/crg }\end{array}$ \\
\hline
\end{tabular}

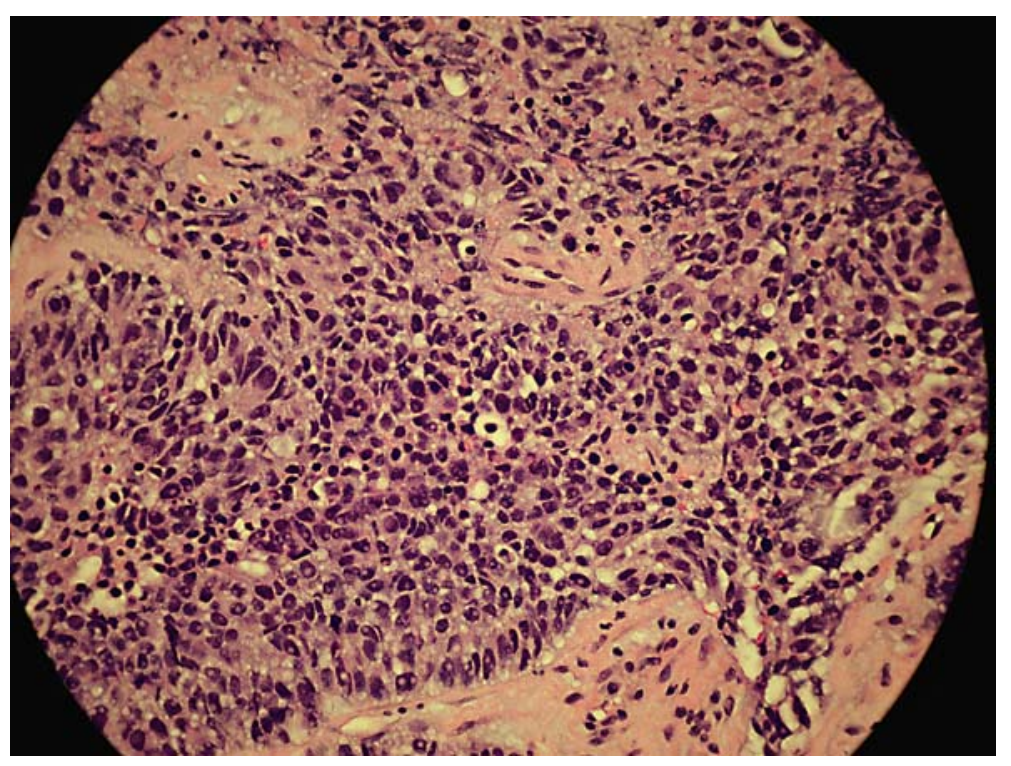

Fig. 1. Photomicrograph of liver biopsy illustrating a metastatic papillary renal cell carcinoma. Immunohistochemical staining revealed PAX-2 positivity and Mucin negativity. A PAX-2 positive stain is highly specific for RCC. A Mucin negative stain suggests against gastric cell carcinoma.
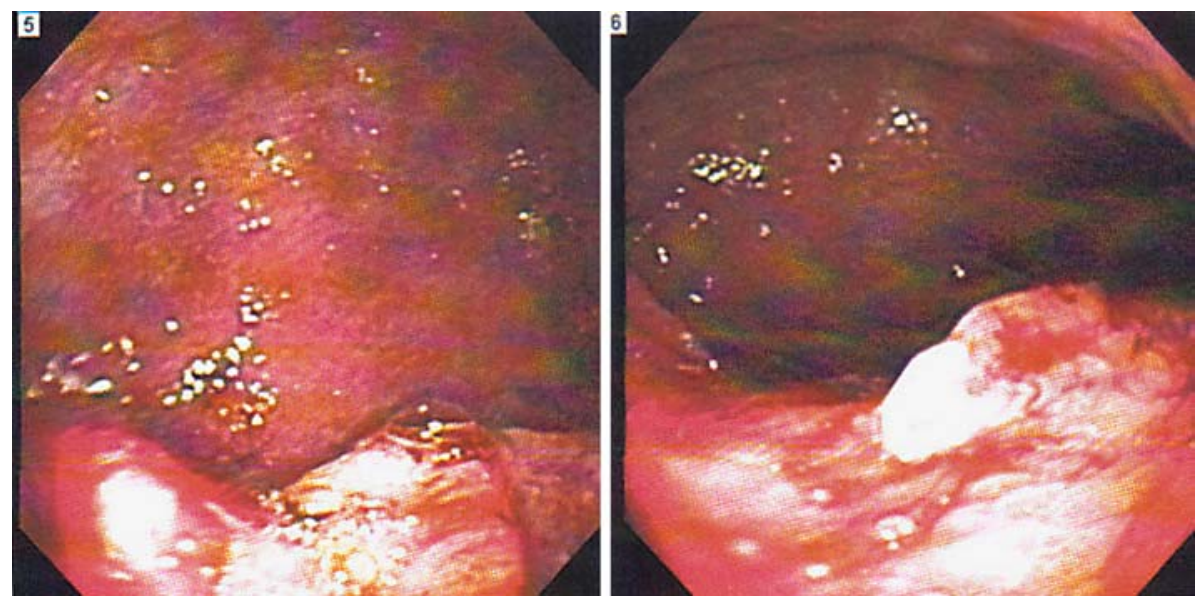

Fig. 2. Superior EGD view discovering a $3 \mathrm{~cm}$ mass in the gastric cardia. 


\begin{tabular}{l|l|l|l}
$\begin{array}{r}\text { Case Reports in } \\
\text { Gastruenterology }\end{array}$ & $\begin{array}{l}\text { Case Rep Gastroenterol 2010;4:421-428 } \\
\text { DOI: 10.1159/000320871 }\end{array}$ & $\begin{array}{l}\text { Published online: } \\
\text { October 5, 2010 }\end{array}$ & $\begin{array}{l}\text { O 2010 S. Karger AG, Basel } \\
\text { ISSN 162-20631 } \\
\text { www.karger.com/crg }\end{array}$ \\
\hline
\end{tabular}

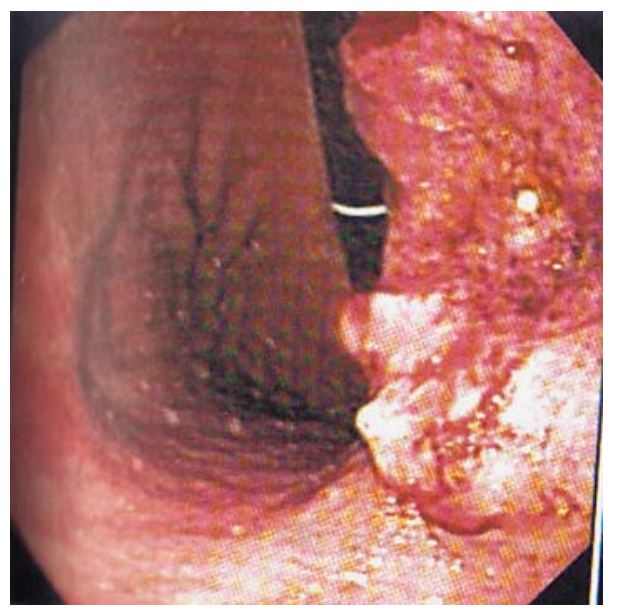

Fig. 3. Horizontal EGD view showing a friable, ulcerated mass with an umbilicated center with central depression.

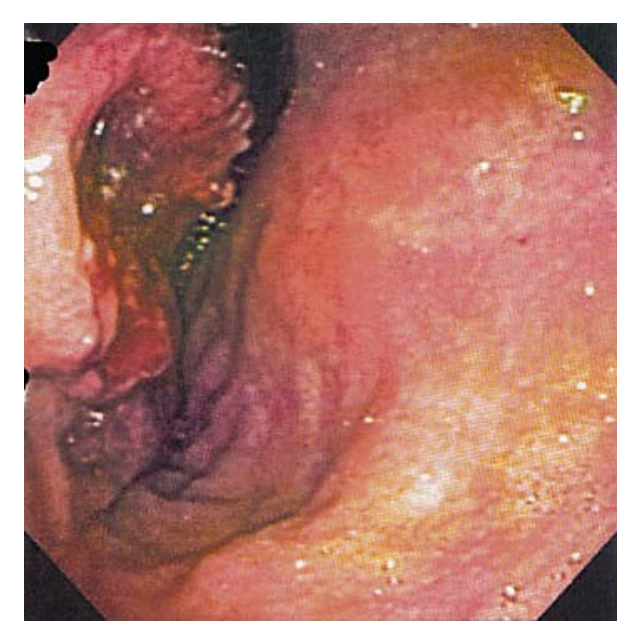

Fig. 4. On EGD, the mass bled on contact prior to biopsy. 


\begin{tabular}{l|l|l|l}
$\begin{array}{r}\text { Case Reports in } \\
\text { Gastruenterology }\end{array}$ & $\begin{array}{l}\text { Case Rep Gastroenterol 2010;4:421-428 } \\
\text { DOI: 10.1159/000320871 }\end{array}$ & $\begin{array}{l}\text { Published online: } \\
\text { October 5, 2010 }\end{array}$ & $\begin{array}{l}\text { O 2010 S. Karger AG, Basel } \\
\text { ISSN 1662-0631 } \\
\text { www.karger.com/crg }\end{array}$ \\
\hline
\end{tabular}

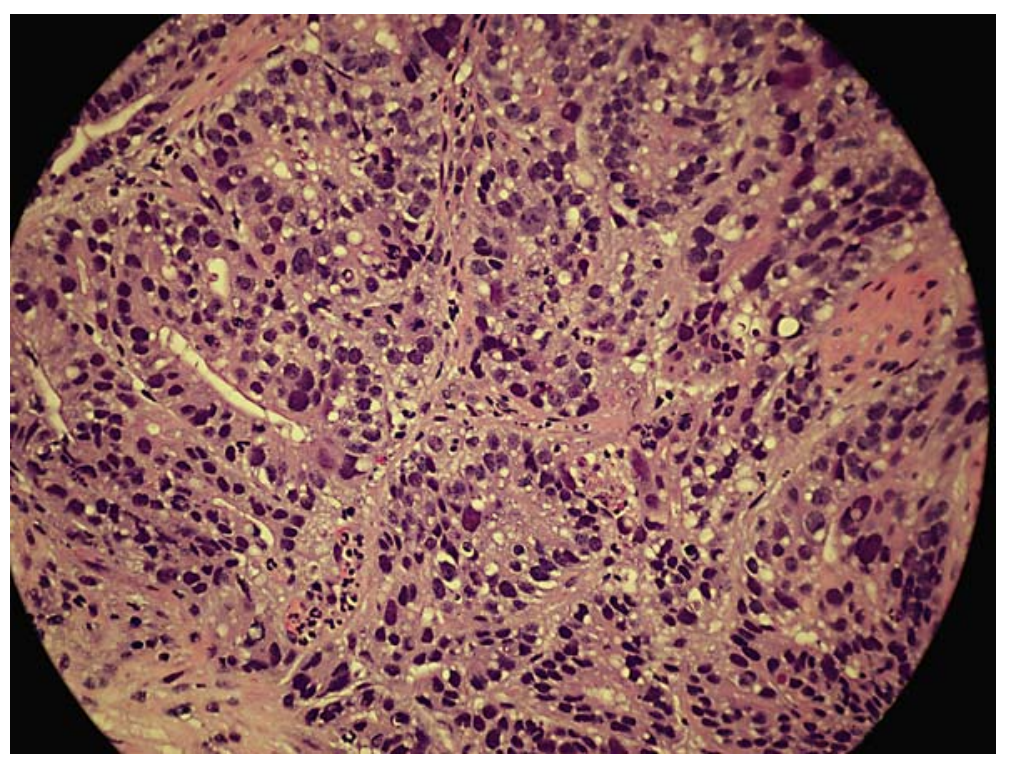

Fig. 5. Photomicrograph of EGD biopsy, which showed classic signet ring morphology.

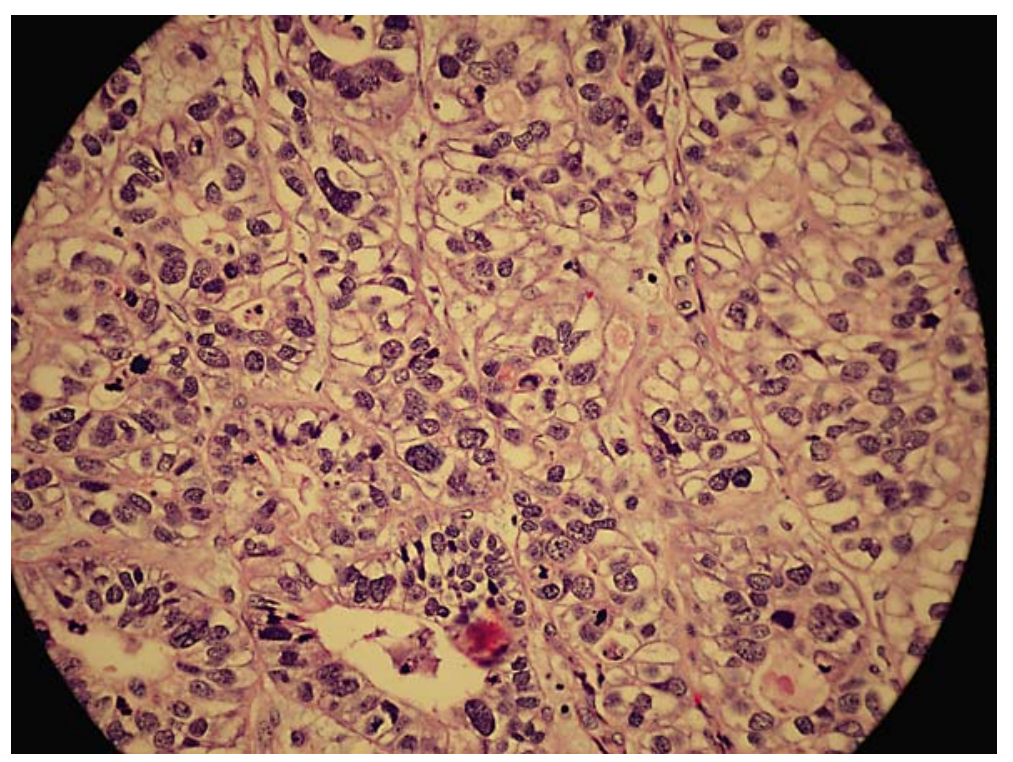

Fig. 6. Photomicrograph of EGD biopsy is consistent with invasive and poorly differentiated gastric cell carcinoma.

\section{References}

1 Diaz JI, Mora LB, Hakam A: The Mainz Classification of renal cell tumors. Cancer Control 1999;6:571-579.

2 Johns Hopkins Hospital Gastroenterology Department. http://www.hopkins-gi.org/GDL_Disease.aspx? CurrentUDV=31\&GDL_Disease_ID=DB2F8EAC-4421-41DD-B04E-684AFEF2AD94\&GDL_DC_ID= E25BDF77-223D-4B6F-9700-5BE41DBDE28B. 
-3 Tol J, Cats A, Mol L, Koopman M, Bos MM, van der Hoeven JJ, Antonini NF, van Krieken JH, Punt CJ: Gastrointestinal ulceration as a possible side effect of bevacizumab which may herald perforation. Invest New Drugs 2008;26:393-397.

4 Devesa SS, Fraumeni JF Jr: The rising incidence of gastric cardia cancer. J Natl Cancer Inst 1999;91:747-749.

-5 Ritchie AW, deKernion JB: The natural history and clinical features of renal carcinoma. Semin Nephrol 1987;7:131-139.

-6 Haffner J, Morel JF, Maunoury V, Caty A, Biserte J, Villers A: Gastric or duodenal metastases from clear cell renal cell carcinoma. Report of two cases and review of the literature (article in French). Prog Urol 2007;17:1305-1309.

-7 Matsutani T, Sasajima K, Miyamoto M, Yokoyama T, Maruyama H, Yanagi K, Matsuda A, Kashiwabara M, Suzuki S, Tajiri T: Resection of pancreatic metastasis from renal cell carcinoma and an early gastric cancer. J Nippon Med Sch 2008;75:41-45.

8 Thyavihally YB, Mahantshetty U, Chamarajanagar RS, Raibhattanavar SG, Tongaonkar HB: Management of renal cell carcinoma with solitary metastasis. World J Surg Oncol 2005;3:48.

-9 Sadler GJ, Anderson MR, Moss MS, Wilson PG: Metastases from renal cell carcinoma presenting as gastrointestinal bleeding: two case reports and a review of the literature. BMC Gastroenterol 2007;7:4.

10 Picchio M, Paioletti A, Santini E, Iacoponi S, Cordahi M: Gastric metastasis from renal cell carcinoma fourteen years after radical nephrectomy. Acta Chir Belg 2000;100:228-230. 